\title{
THE RELATION OF THE STAPHYLOCOCCAL $\alpha$-ANTIHAEMOLYSIN TITRE TO INFECTION IN THE NEWBORN
}

\author{
BY \\ K. CHLOUVERAKIS, L. L. GRIFFITHS and P. N. SWIFT
From Farnborough Hospital, Kent
}

(RECEIVED FOR PUBLICATION JANUARY 29, 1963)

The mechanisms responsible for immunity to staphylococci and to the exotoxins that they produce are, in spite of much research, not yet fully understood. Much of the work in this field was carried out in the first half of this century before antibiotics became available and now that the limitations of antibiotic therapy are more clearly defined it is again receiving attention. The transfer of antibody and of staphylococcal $\alpha$-antihaemolysin from the mother to the infant and its significance in protecting against infection have been the subject of numerous reports. There remain, however, certain features such as the higher titres of antihaemolysin in the infant than the mother, the time in gestation at which transfer occurs and the protective effect of this antitoxin, which require clarification. The present study has been undertaken with these objects in mind and particularly to define the part played by staphylococcal $\alpha$-antihaemolysin in the newborn infants' resistance to infection.

\section{Material and Methods}

Four groups of patients have been studied:

Group 1: 235 women at the 36th week of pregnancy.

Group 2: The newborn babies of Group 1 born in hospital.

Group 3: 362 women in the puerperium (all different from those in Group 1).

Group 4: The newborn babies of Group 3 born in the same hospital.

Venous blood $(5-10 \mathrm{ml}$.) was taken from mothers of Group 1 when attending the antenatal clinic, and of Group 3, within the first $\mathbf{4 8}$ hours after delivery. Cord blood $(5-10 \mathrm{ml}$.) was collected from their babies immediately after birth. The serum was separated and stored in the refrigerator until tested.

Sera were titrated for staphylococcal $\alpha$-antihaemolysin by the following method:

Staphylococcal $\alpha$-haemolysin (dried) (Wellcome Diagnostic Reagent) was reconstituted in nutrient broth and diluted in saline, to give six consecutive dilutions containing respectively $4,2,1,0.5$, and 0.25 and 0.125 units per ml. $0 \cdot 1 \mathrm{ml}$. of each dilution was put into testtubes; the same amount of serum, previously inactivated at $56^{\circ} \mathrm{C}$. for 30 minutes, was added after being cooled, and the tubes were shaken and left at room temperature for a minimum of 30 minutes. $0 \cdot 1 \mathrm{ml}$. of a $10 \%$ suspension in saline of thrice-washed rabbit erythrocytes was then added. The tubes were shaken and incubated at $37^{\circ} \mathrm{C}$. in a water-bath for two hours, after which they were observed for the occurrence of haemolysis. The first tube in which partial haemolysis was observed was taken as end-point, and if no such tube was present in the series the mid-point between the dilution of the last tube with complete haemolysis and that with no haemolysis was taken as end-point.

For Groups 3 and 4 a second reading was perfurmed after the tubes had been in the refrigerator for 12 hours, which has been taken into account in all the results.

Nasal swabs were taken from all subjects in Groups 3 and 4 within 48 hours and between the 8th and 10th day after delivery, before the mother and baby were discharged home. Staphylococci were tested for coagulase by the slide technique, and in cases of ambiguity also by the tube technique, and those that produced coagulase were regarded as pathogenic.

The occurrence of clinical infection in the infants belonging to both Groups 2 and 4 was determined by daily examination by the nursing staff in the first instance, and confirmed by the paediatric registrar. In every case of infection, swabs were taken from the site to determine the infecting agent.

\section{Results}

Titre of Staphylococcal $\alpha$-antihaemolysin. (a) Figs. 1,2 and 3 show a frequency distribution of the titre of staphylococcal $\alpha$-antihaemolysin in Groups 1,3 and 4 respectively. All these distributions are asymmetrical and similar to each other, reaching a maximum titre (mode) of 0.75 unit, and tailing off slowly as higher titres are reached. 


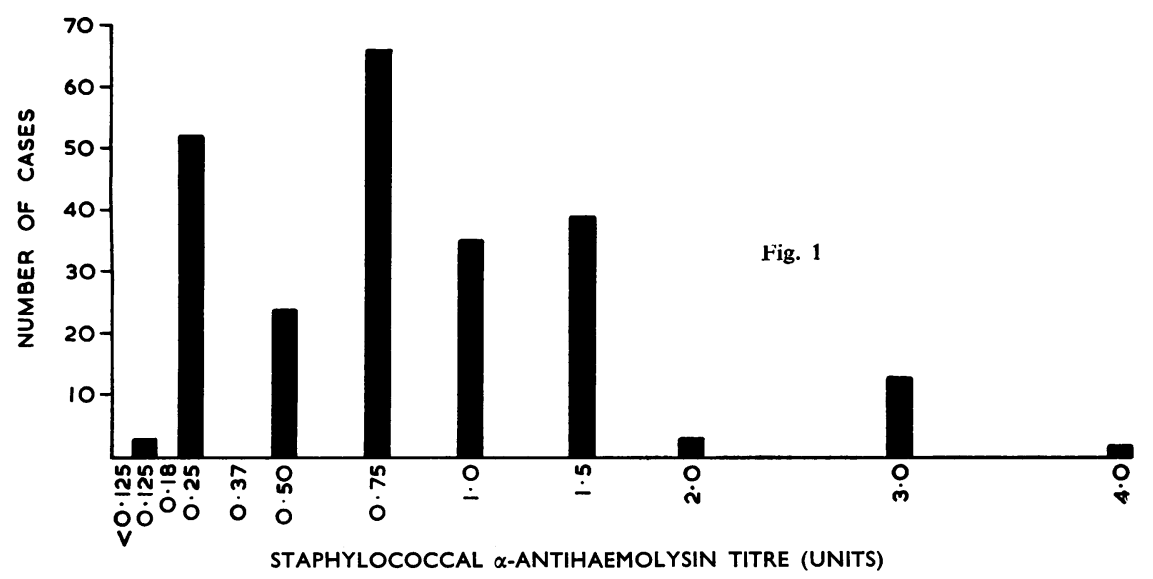

FIG. 1.-Distribution of maternal titres (Group 1). Fig. 2.-Distribution of maternal titres (Group 3). FIG. 3.-Distribution of infant titres (Group 4).

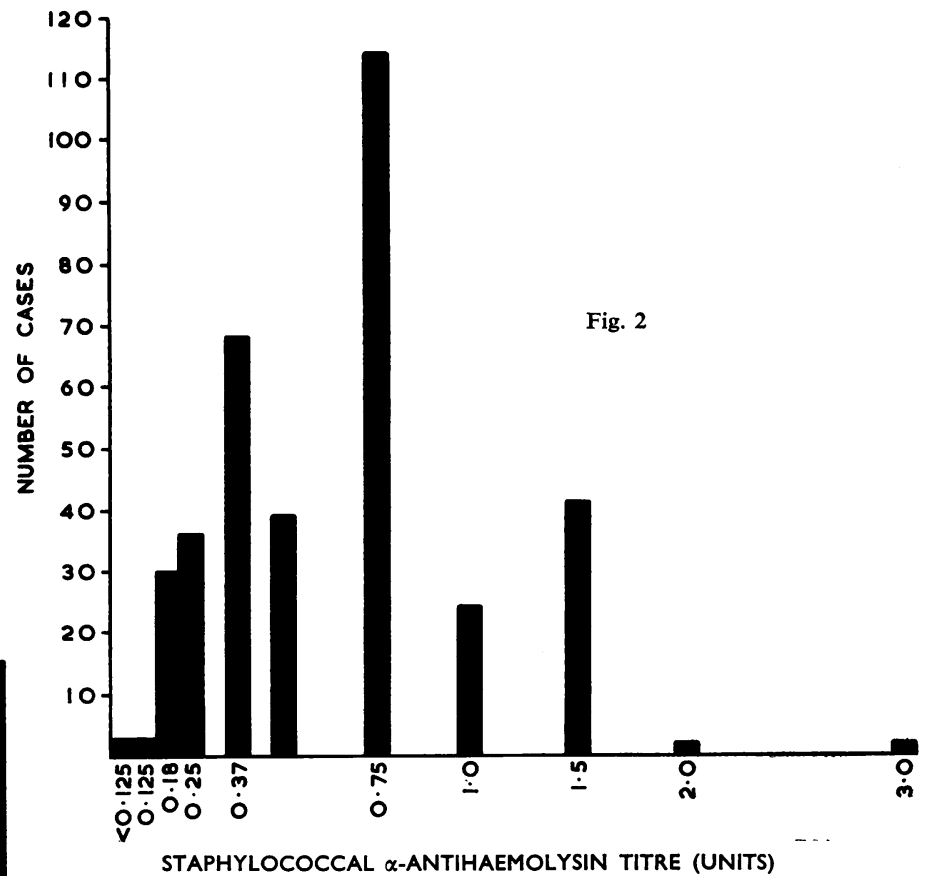

Fig. 3

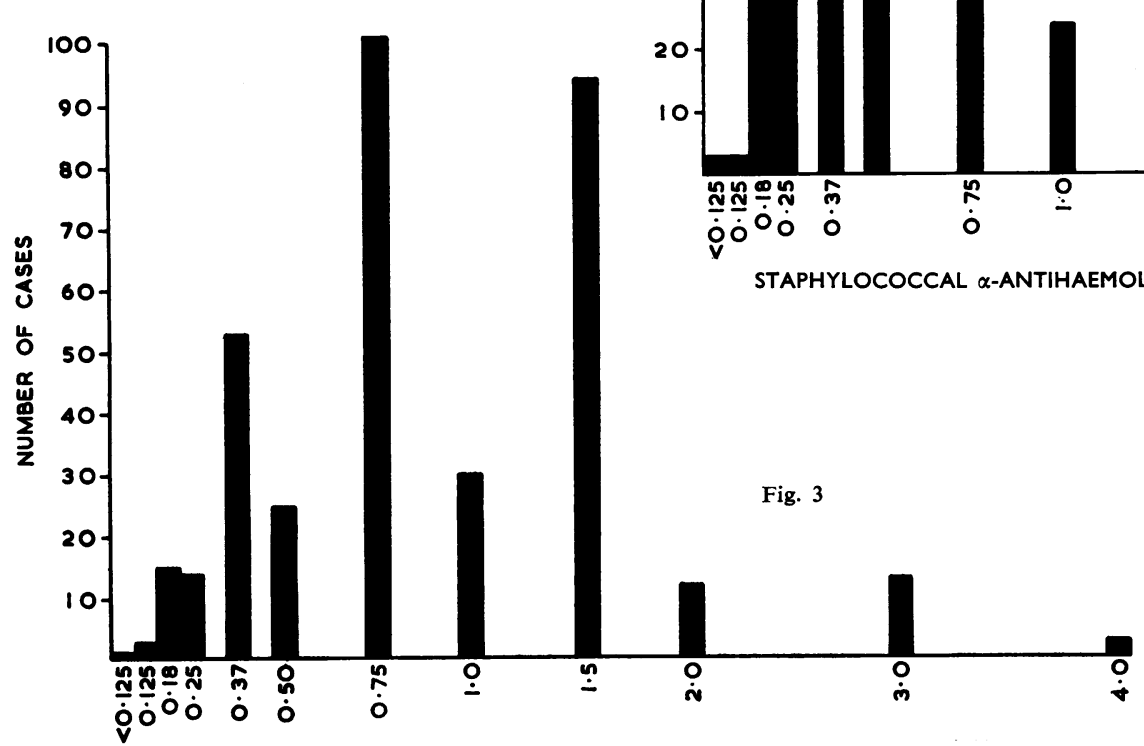

STAPHYLOCOCCAL $\alpha$-ANTIHAEMOLYSIN TITRE (UNITS 


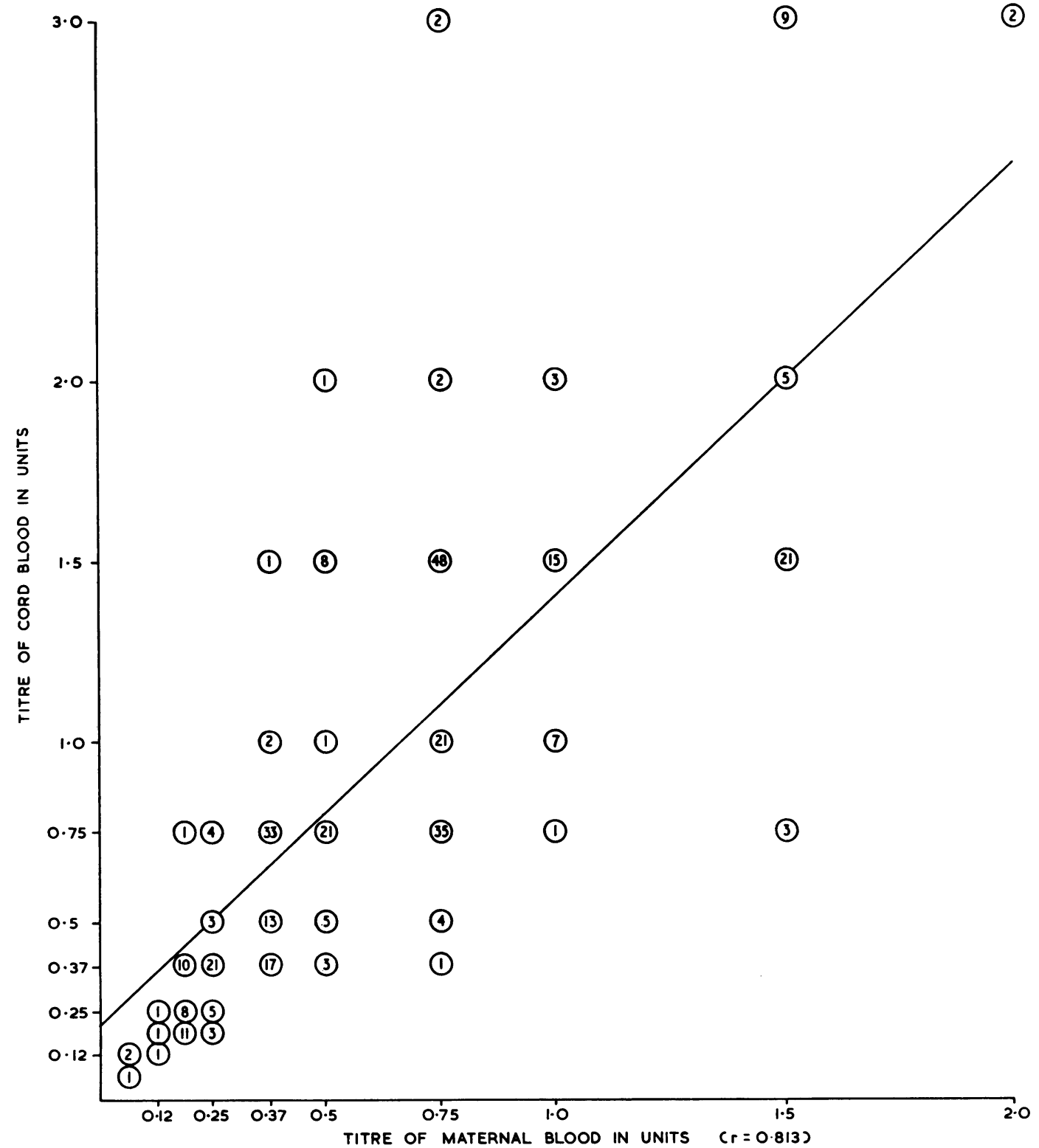

Fig. 4.-Relation between staphylococcal $\alpha$-antihaemolysin titres of maternal and cord blood. In addition to the figures shown, two mothers with titres of 1.5 had infants with titres of 4 , and one mother with a titre of 3 had an infant with a titre of 2.

(b) Fig. 4 shows the relation between the titre of staphylococcal $\alpha$-antihaemolysin in the newborn babies of Group 4 and their mothers of Group 3. The average of the newborns' titre is $0.99 \pm 0.68$ (mean \pm S.D.) and that of the mothers' $0.66 \pm 0.44$ (mean \pm S.D.).
From Fig. 4 it is apparent that infants tend to have higher titres than their mothers; of the 362 infants who were examined, 241 had higher titres, 106 had similar titres and only 15 had lower titres than their mothers.

The regression equation between infants' and 
mothers' titres is $y=120 x+0 \cdot 20$, where $y$ stands for the infants' and $x$ for the mothers' titre; the correlation coefficient being $\mathrm{r}=0.813$ with $\mathrm{p}<0 \cdot 0001$.

The possibility that staphylococcal infection in the mother during pregnancy might influence the titre has been examined and we have, as might be expected, been unable to find any such correlation. Likewise we have examined the titres in relation to weight at birth and duration of pregnancy and have been unable to demonstrate that these have any influence on the height of the infants' titre. Premature infants of low birth weight and full-term infants and overdue infants of low birth weight seem as likely as full-term infants of normal birth weight to have higher titres than their mothers. Overdue infants of high weight also had titres indistinguishable from those expected.

Bacteriological Status of Clinically Infected Infants. Of the 597 infants examined, 41 showed clinical evidence of infection which with the exception of one who developed septicaemia following a staphylococcal infection of the umbilicus, were mild superficial infections of eyes, skin or umbilical cord.

Coagulase positive staphylococci were isolated from 24, coagulase negative staphylococci were isolated from 7 , and miscellaneous micro-organisms including monilia, Esch. coli and streptococci were obtained from 10.

Nasal Carriage and Liability to Clinical Infection.

Table 2 shows the incidence of colonization in the mothers and babies of Groups 3 and 4 .

In 19 of the 362 infants in Group 4 who developed clinical and bacteriological evidence of staphylococcal infection (Table 3), this micro-organism was cultured also from the nose on at least one occasion in 14 . In view of the fact that only two nasal swabs were taken the incidence of nasal carriage may well have been higher. It is in keeping nevertheless with accepted views on the close relation between colonization and infection rates.

Relation Between Maternal Titre and Staphylococcal Infection in the Infant. A contingency table (Table 1) between the titre of mothers in Groups 1 and 3 and the numbers of clinically infected and non-infected infants in Groups 2 and 4 has been constructed. Due, however, to the small number of infected infants in some of the cells the maternal titres have been pooled into three classes. $\chi^{2}$ was calculated with Yates correction for continuity and was found to be 0.33 with $p>0 \cdot 95$. No association between the maternal
TABLE 1

RELATION OF ANTIHAEMOLYSIN TITRE TO INCIDENCE OF INFECTION

\begin{tabular}{|c|c|c|c|c|}
\hline Maternal Titre & & $\begin{array}{l}\text { Number of } \\
\text { Infected } \\
\text { Infants }\end{array}$ & $\begin{array}{l}\text { Number of } \\
\text { Non-infected } \\
\text { Infants }\end{array}$ & Total \\
\hline $\begin{array}{l}0-0 \cdot 37 \text { units } \ldots \\
0 \cdot 5-1 \cdot 0 \text { units } \ldots \\
1 \cdot 5 \text { units and over }\end{array}$ & $\begin{array}{c}\ldots \\
\cdots \\
.\end{array}$ & $\begin{array}{r}9 \\
10(12 \cdot 8) \\
5(4 \cdot 1)\end{array}$ & $\begin{array}{r}195(186 \cdot 2) \\
292(289-9) \\
96(96 \cdot 9)\end{array}$ & $\begin{array}{l}194 \\
302 \\
101\end{array}$ \\
\hline Total & .. & 24 & 573 & 597 \\
\hline
\end{tabular}

Numbers in parentheses show expected frequencies.

TABLE 2

NASAL FLORA IN 363 MOTHERS (GROUP 3) AND 362 INFANTS (GROUP 4)

\begin{tabular}{|c|c|c|c|c|}
\hline & \multicolumn{2}{|c|}{ First Swab } & \multicolumn{2}{|c|}{ Second Swab } \\
\hline & $\begin{array}{c}\text { Coagulase } \\
\text { Positive } \\
\text { Staphylococci }\end{array}$ & Other & $\begin{array}{c}\text { Coagulase } \\
\text { Positive } \\
\text { Staphylococci }\end{array}$ & Other \\
\hline $\begin{array}{l}\text { Mothers } \\
\text { Infants }\end{array}$ & $\begin{array}{r}126 \\
48\end{array}$ & $\begin{array}{l}236 \\
220\end{array}$ & $\begin{array}{l}123 \\
154\end{array}$ & $\begin{array}{l}181 \\
150\end{array}$ \\
\hline
\end{tabular}

TABLE 3

TITRE OF STAPHYLOCOCCAL $\alpha$-ANTIHAEMOLYSIN IN NEWBORNS INFECTED WITH PATHOGENIC STAPHYLO COCCI (GROUP 4) AND THEIR MOTHERS (GROUP 3)

\begin{tabular}{c|c|c}
\hline Maternal Titre & Cord Blood Titre & No. of Cases \\
\cline { 1 - 2 } 0.18 & 0.18 & 1 \\
0.25 & 0.37 & 2 \\
0.25 & 0.75 & 1 \\
0.37 & 0.5 & 2 \\
0.37 & 0.75 & 1 \\
0.75 & 0.5 & 1 \\
0.75 & 0.75 & 1 \\
0.75 & 1.0 & 3 \\
0.75 & 1.5 & 1 \\
1.0 & 0.75 & 1 \\
1.0 & 1.0 & 1 \\
1.5 & 0.75 & 2 \\
1.5 & 1.5 & 1 \\
1.5 & 4.0 & \\
\hline
\end{tabular}

titres of staphylococcal $\alpha$-antihaemolysin and the liability of the infant to clinical staphylococcal infection can thus be demonstrated.

\section{Discussion}

Although much work has already been carried out on the estimation of the levels of $\alpha$-antihaemolysin (Bryce and Burnet, 1932; Parish, O'Meara and Clark, 1934) the lack of an International Unit renders the results found in different countries incomparable and makes it impossible to refer to estimations done before 1935 when the Committee of the Health Organization (League of Nations) established a provisional International Standard for staphylococcal antitoxin. However, most workers agree that there is a wide variation in titre among healthy populations. 
In the present patients titres ranged from 0.062 I.U. to 4.0 I.U. with a mode at 0.75 I.U. Newborns are known to have similar levels to those found in their mothers (Nélis and Poncelet, 1935; Murray, 1935), and their titres decrease gradually over the first few months. With the acquisition of active immunity they rise again to reach adult levels by approximately the third year. In our experiments $66 \%$ of newborn infants had higher titres than their mothers; in $29.28 \%$ the titres were equal to those of the mother and in only $4.14 \%$ lower than the mothers. These results are thus similar to those of Bryce and Burnet (1932), Dóbiás, Balló and Keményv́ari (1957) and other workers. The higher titres in our cases cannot, however, be due to breast feeding as suggested by Dóbiás et al. (1957), since the titrations were performed on cord blood. Longsworth, Curtis and Pembroke (1945) studied electrophoretically maternal and infant plasmas and sera and showed that although infants have lower values of total globulin than their mothers, the $\gamma$-globulin fraction is high and the ratios of $\gamma$-globulin to total globulin are, without exception, significantly higher than those of their mothers. It seems, therefore, that the transplacental transfer of staphylococcal $\alpha$-antihaemolysin is likewise differentially favoured.

It is of interest also that the titres of premature babies, including those born as early as the 31 st week of pregnancy, that have been examined in this series do not differ from those of the full-term infants, and this supports the view that transfer across the placenta is taking place at least as early as the 31 st week and does not take place immediately before full-term delivery as suggested by Orlandini, Sass-Kortsak and Ebbs (1955).

In relating the incidence of infection in the infant to staphylococcal $\alpha$-antihaemolysin titre we employed the maternal titre only, in view of the small difference and close correlation between maternal and cord titres. By this method our results (Table 1) failed to show any association between titre and infection.

The importance of the aetiological role of colonization by staphylococci in causing staphylococcal disease is borne out by the findings in this series, though the number of infected newborns is too small to permit statistical proof. From the simple extraction of percentages, we find that at least $14(74 \%)$ of the 19 infected newborns had been carriers compared with 154 out of $362(42 \cdot 5 \%)$ for the group as a whole, and it is reasonable to assume that liability to develop clinical evidence of infection is related to the colonization (Monro and Markham, 1958; Gillespie, Simpson and Tozer, 1958; Cope, Shooter, Green and Noble, 1961).

Not only may we conclude that the level of staphylococcal antihaemolysin in the blood bears no demonstrable relation to the occurrence of staphylococcal infection in the newly born, but also that it does not influence colonization of the skin and nose. We consider that this antitoxin is either not the principal protecting factor or that its estimation does not provide a quantitative measure of immunity in accordance with the work of Johanovský (1958).

\section{Summary}

Titres of staphylococcal $\alpha$-antihaemolysin have been estimated in 597 mothers and their infants. Titres in the infants' sera were commonly higher than in the mothers', and this finding was not attributable to breast-feeding.

No correlation could be demonstrated between the height of the titre and the liability of the infant to staphylococcal colonization or clinical infection. The titres in infants of low birth weight, whether premature or full term, were found not to be significantly lower than those of normal or high birth weight.

\section{REFERENCES}

Bryce, L. M. and Burnet, F. M. (1932). Natural immunity to staphylococcal toxin. J. Path. Bact., 35, 183.

Cope, A., Shooter, R. A., Green, S. H. and Noble, W. C. (1961). Nasal carriage of Staph. aureus by newborn babies. Brit. med.J., $2,329$.

Dóbiás, G., Balló, T. and Keményv́ari, J. (1957). Uber den Einfluss des Kolostrums auf den Staphylokokken- $\alpha$-Antitoxintiter der Neugeborenen. Z. Immun. Forsch., 114, 105.

Gillespie, W. A., Simpson, K. and Tozer, R. C. (1958). Staphylococcal infection in a maternity hospital: Epidemiology and control. Lancet, 2, 1075.

Johanovský, J. (1958). Die Bedeutung des Antileukozidins und Antitoxins bei der Immunität gegen Staphylokokken-InfekAnen. Z. Immun.-Forsch., 116, 318 .

Longsworth, L. G., Curtis, R. M. and Pembroke, R. H., Jr. (1945). The electrophoretic analysis of maternal and fetal plasmas and sera. J. clin. Invest., 24, 46.

Monro, J. A. and Markham, N. P. (1958). Staphylococcal infection in mothers and infants: Maternal breast abscesses and antecedent neonatal sepsis. Lancet, $2,186$.

Murray, D. S. (1935). Staphylococcus toxoid. A clinical trial. ibid., 1, 303.

Nélis, P. and Poncelet, F. (1935). L'antitoxine staphylococcique naturelle chez l'homme. C.R. Soc. Biol. (Paris), 118, 312.

Orlandini, O., Sass-Kortsak, A. and Ebbs, J. H. (1955). Serum gamma globulin levels in normal infants. Pediatrics, 16, 575.

Parish, H. J., O'Meara, R. A. Q. and Clark, W. H. M. (1934). The clinical investigation of staphylococcal toxin, toxoid, and antitoxin. Lancet, 1, 1054. 